\title{
Field evidence for an association between growth and protein polymorphism in the acorn barnacle Semibalanus balanoides
}

\author{
David Véliz ${ }^{1,3}$, Edwin Bourget ${ }^{2}$, Louis Bernatchez ${ }^{1, *}$ \\ ${ }^{1}$ Québec Océan, Département de Biologie, Université Laval, Québec, Québec G1K 7P4, Canada \\ ${ }^{2}$ Vice-rectorat à la recherche, Université de Sherbrooke, Sherbrooke, Québec J1K 2R1, Canada \\ ${ }^{3}$ Present address: Departamento de Ciencias Ecológicas, Facultad de Ciencias, Universidad de Chile, Las Palmeras 3425 , \\ Nuñoa, Santiago, Chile
}

\begin{abstract}
Organisms living in highly heterogeneous environments are useful for examining the effects of associations between phenotypes and ecologically relevant genes in the field. Here, we tested the null hypothesis of no association between the variation in 2 fitness-related traits (growth and fecundity) and polymorphism at 2 enzymatic loci, $M P I^{*}$ and $G P I^{*}$, known to be subject to strong spatial selection. We also tested if such an association was related to the intensity of genotype selection observed for both allozymes at sampling locations in 2 barnacle cohorts. For both cohorts, individuals with the $G P I^{*} 286 / 286$ genotype were larger in size than individuals with the $G P I^{*} 100 / 100$ genotype, particularly in sites and microhabitats south of the Miramichi Estuary, Gulf of St. Lawrence, Canada. This coincided with a reduced $G P I^{*} 100 / 100$ frequency in this region. In contrast, the growth-MPI* genotype association showed no clear pattern. Overall, our results indicate that the phenotype-genotype association differed strikingly between the 2 genes, and that both the growth-GPI* genotype association and genotype selection occur in localities south of the Miramichi Estuary only, and at different times during development, first a few days after settlement (genotype selection) and later through growth-genotype association.
\end{abstract}

KEY WORDS: Natural selection $\cdot$ Phenotype-genotype association $\cdot$ Allozyme $\cdot M P I^{*} \cdot G P I^{*} \cdot M a r i n e$ invertebrates

\section{INTRODUCTION}

Adaptation of organisms to heterogeneous environments depends on genetic diversity and its potential to minimize negative effects on fitness. Thus, population persistence in heterogeneous environments is possible by maintaining stable variability of these genes and later by maximising phenotypic characteristics that confer more efficiency in each habitat (Feder \& Watt 1992). Empirical studies on ecologically relevant genes corroborate this idea. For instance, enzymes utilising substrates from the external environment have been reported to be more polymorphic than those utilising internal metabolites (Gillespie \& Kojima 1968, Kojima et al. 1970). Previous studies also demonstrated that allozyme genotypes which perform differently confer different survivorship, behaviour and mating in some organisms (Watt et al. 1983, 1985, Dimichele \& Powers 1991, Powers et al. 1991, Watt 1992, 1994). This is because enzymes control the rate of energy flow through the metabolic pathways, thereby controlling the rate of growth and development as well as influencing the proportion of energy allocated to various functions (Heinrich 1977, Mitton 1997). Thus, the link between genetic variability and phenotypic traits is relevant to the study of the adaptation of organisms to heterogeneous environments.

In marine invertebrates, most studies have either focussed on the effects of enzyme performance (metabolic rate) as a phenotypic trait (e.g. Koehn et al. 1983) or the heterozygosity-fitness correlation (global effects) and phenotypic traits such as fecundity and individual 
growth (Diehl \& Koehn 1985, Hansson \& Westerberg 2002). However, few studies have tested for an association between the genotypic composition of specific candidate genes to fitness-related traits (e.g. Schmidt 2001). This is particularly true for studies conducted in the field (but see Planes \& Romans 2004).

Recent studies on the acorn barnacle Semibalanus balanoides revealed that this species could be a model for studying phenotypic and genotypic adaptation in the natural environment. This species is a hermaphroditic and obligate cross-fertilised species (Barnes \& Crisp 1956) with a planktonic larval development (Bassindale 1936). Sessile adult individuals inhabit the intertidal, a highly heterogeneous environment (fluctuating salinity, extreme temperatures, desiccation, wave action, solar radiation, etc.) (Raffaelli \& Hawkins 1996). Several fitness-related traits, including survival, gametogenesis, fertilisation, and incubation time are affected by environmental variation encountered by the acorn barnacle (Bousfield 1953, 1955, Southward 1958, Barnes 1959, Barnes \& Barnes 1965, 1976, Bergeron \& Bourget 1984, 1986, Bertness \& Gaines 1993, Brind'Amour et al. 2002). Moreover, previous studies supported the hypothesis that 2 allozymes (mannose phosphate isomerase [MPI; EC 5.1.3.8] and glucose phosphate isomerase [GPI; EC 5.1.3.9]) undergo pronounced directional selection along the Atlantic coast of North America (Holm \& Bourget 1994, Rand et al. 2002, Véliz et al. 2004, 2006). Specifically, in the Gulf of St. Lawrence, New Brunswick, Canada, alleles from these 2 allozymes experience changes in frequency associated with environmental constraints in heterogeneous environments on regional scales (Holm \& Bourget 1994, Dufresne et al. 2002). Thus, both $M P I^{*}$ and $G P I^{*}$ are possibly subject to strong directional selection south of the Miramichi Estuary, Gulf of St. Lawrence, whereas neutrality cannot be ruled out at sampling sites and microhabitats located north of the estuary (Véliz et al. 2004).

In this context, our main goal was to test the null hypothesis of no association between the variation in 2 fitness-related traits (growth and fecundity) (Ramirez 2002) and polymorphism of the $M P I^{*}$ and $G P I^{*}$ genotypes. We then tested if such an association, if present, was related to the genotype selection observed for both allozymes at sampling locations.

\section{MATERIALS AND METHODS}

Sampling sites. Samples were taken from intertidal sites on the Gulf of St. Lawrence, as described in Véliz et al. (2004). Two cohorts of barnacles (2000 and 2001) were sampled during 5 periods: early June (during larval settlement, labelled June 1), mid-June (2 wk after settlement, labelled June 2), August, October, and April-May (after ice scouring). For the Cohort 2000, 1 northern (Burnt Church) and 1 southern (Cap Lumière) site relative to the mouth of the Miramichi Estuary, were sampled whereas 2 northern (Le Goulet and Shippagan) and 2 southern (Pointe Sapin and Cap Lumière) sites were sampled for the Cohort 2001. Four categories of microhabitats were defined at each site according to the criteria shore level (high $[\mathrm{H}]$ and low [L] intertidal) and exposure to sun (exposed [E] and sheltered [S]). The statistical analysis of Véliz et al. (2004) has shown that microhabitats have different thermal and desiccation stress levels, with HE > LE > HS $>$ LS.

Considering that all individuals have a similar size at settlement and that settlement occurs within 3 or $4 \mathrm{~d}$ (E. Bourget unpubl. data), one can assume that all individuals start the benthic stage at approximately the same date. Therefore, individual size was a valid proxy for an estimate of growth. In order to test for growth and genotype association, a total of 7214 barnacles were collected and placed in a liquid nitrogen container until storage at $-80^{\circ} \mathrm{C}$. The number of barnacles sampled for each microhabitat varied between 14 and 207 (mean $=80.93)($ Table 1$)$. The maximal length (rostro-carinal length) of each individual was measured to the nearest $0.01 \mathrm{~mm}$ using a stereomicroscope with an ocular micrometer. Because barnacles are easily broken during sampling, several individuals were collected incomplete. For this reason and in order to avoid possible error in length measurements, we used only complete individuals. This explains why sample size differs from that given in Véliz et al. (2004). Cap Lumière (October 2000) has a sample size larger than in Véliz et al. (2004), since additional analyses were carried out.

We used the number of larva from each larval mass as a measurement of fecundity. For this purpose, larval masses from 40 barnacles were taken at each microhabitat and site in May (before larval release) and stored in liquid nitrogen. Individuals were dissected and all larvae were isolated from the mantle cavity and counted. To avoid analysis error due to female mass larvae loss during sampling, the analysis was performed with data from barnacles with an apparently complete larvae mass only.

Allozyme electrophoresis. The genetic data used in this study to test for an association between genotypes and fitness-related traits were generated in Véliz et al. (2004). Briefly, for all samples, tissue from each individual was homogenised with a $5 \mathrm{ml}$ homogenisation buffer ( $\mathrm{pH}=8.5)$ (Tremblay et al. 1998), and migration was performed on a cellulose acetate gel and stained according to Hebert \& Beaton (1989). For both loci $\left(M P I^{*}\right.$ and $\left.G P I^{*}\right), 2$ rare alleles with a low frequency 
Table 1. Semibalanus balanoides. Number of barnacles analysed $\left(G P I^{*} / M P I^{*}\right)$ for size-genotype association in different cohorts, on different dates and at different sites and microhabitats. HS: high sheltered; HE: high exposed; LS: low sheltered; LE: low exposed; -: no settlers; D: died

\begin{tabular}{|c|c|c|c|c|c|}
\hline \multirow{2}{*}{ Site } & \multirow{2}{*}{ Date } & \multicolumn{4}{|c|}{ - Microhabitats } \\
\hline & & HS & $\mathrm{HE}$ & LS & LE \\
\hline \multicolumn{6}{|c|}{ Cohort 2000} \\
\hline Burnt & Jun 1 & $14 / 14$ & - & $26 / 26$ & - \\
\hline \multirow[t]{4}{*}{ Church } & Jun 2 & $21 / 21$ & - & $68 / 68$ & - \\
\hline & Aug & $32 / 32$ & - & $38 / 38$ & - \\
\hline & Oct & $72 / 72$ & - & 94/94 & - \\
\hline & May & $88 / 90$ & - & $94 / 94$ & - \\
\hline Cap & Jun 1 & $69 / 69$ & $58 / 58$ & $67 / 67$ & $67 / 67$ \\
\hline \multirow[t]{4}{*}{ Lumière } & Jun 2 & $62 / 62$ & $72 / 75$ & $80 / 80$ & $80 / 80$ \\
\hline & Aug & $81 / 81$ & $40 / 40$ & $83 / 83$ & $83 / 83$ \\
\hline & Oct & $126 / 120$ & $79 / 79$ & $207 / 177$ & $136 / 136$ \\
\hline & May & 41/41 & $36 / 36$ & $75 / 75$ & $42 / 42$ \\
\hline \multicolumn{6}{|c|}{ Cohort 2001} \\
\hline \multirow[t]{5}{*}{ Shippagan } & Jun 1 & $87 / 87$ & $89 / 89$ & $86 / 86$ & 89/89 \\
\hline & Jun 2 & $87 / 87$ & D & $89 / 89$ & $89 / 89$ \\
\hline & Aug & 90/89 & D & $87 / 87$ & $88 / 87$ \\
\hline & Oct & $89 / 89$ & D & $88 / 88$ & $90 / 78$ \\
\hline & May & $88 / 88$ & D & $90 / 90$ & $73 / 73$ \\
\hline \multirow[t]{5}{*}{ Le Goulet } & Jun 1 & $84 / 83$ & - & $83 / 83$ & - \\
\hline & Jun 2 & $85 / 84$ & - & $85 / 85$ & - \\
\hline & Aug & $75 / 70$ & - & $89 / 88$ & - \\
\hline & Oct & $88 / 88$ & - & $86 / 86$ & - \\
\hline & May & $88 / 88$ & - & 89/89 & - \\
\hline Pointe & Jun 1 & $88 / 88$ & $89 / 88$ & $88 / 87$ & $81 / 82$ \\
\hline \multirow[t]{4}{*}{ Sapin } & Jun 2 & $83 / 84$ & D & $80 / 79$ & $88 / 86$ \\
\hline & Aug & $78 / 74$ & D & $88 / 89$ & 86/88 \\
\hline & Oct & 90/90 & D & $88 / 88$ & D \\
\hline & May & $87 / 87$ & $\mathrm{D}$ & $89 / 89$ & D \\
\hline Cap & Jun 1 & $78 / 78$ & $87 / 87$ & $87 / 88$ & $88 / 88$ \\
\hline \multirow[t]{4}{*}{ Lumière } & Jun 2 & $67 / 67$ & $69 / 67$ & $84 / 79$ & $84 / 84$ \\
\hline & Aug & 88/86 & $86 / 87$ & $86 / 86$ & 88/88 \\
\hline & Oct & $88 / 90$ & $90 / 90$ & $90 / 90$ & $90 / 90$ \\
\hline & May & $89 / 89$ & D & $90 / 90$ & $89 / 89$ \\
\hline
\end{tabular}

$(<1 \%)$ were not considered in the analysis. Thus, 3 genotypes of GPI $^{*}\left(G P I^{*} 100 / 100, G P I^{*} 100 / 286\right.$ and $\left.G P I^{*} 286 / 286\right)$ and $M^{*} I^{*}\left(M P I^{*} 85 / 85, M P I^{*} 85 / 100\right.$ and $\left.M P I^{*} 100 / 100\right)$ were used for all analyses.

Data analysis. We used factorial ANOVA to test the effect of Genotype, Microhabitat, Date and Site on barnacle growth. All factors were considered fixed, and a significance threshold of 0.05 was used. Data were log-transformed, according to the Box-Cox method to normalise variance, using the SAS statistical package (SAS Institute 1998). Normality and homoscedasticity was observed by graphical examination of residuals (Montgomery 2001). To analyze Cohort 2000, we performed a factorial ANOVA with Date (June 1, June 2, August, October and May), Site (Burnt Church and Cap Lumière), Microhabitat (HE, HS, LE and LS), and Genotype ( 2 homozygotes and 1 heterozygote) as factors. For Cohort 2001, a factorial nested ANOVA was performed with Date $(\mathrm{n}=5)$, Geographic region $(\mathrm{n}=2)$, Microhabitat $(\mathrm{n}=4)$, Genotype $(\mathrm{n}=3)$ and Site ( $\mathrm{n}=4$ ) nested within Geographic region (north: Le Goulet and Shippagan; south: Pointe Sapin and Cap Lumière). $M P I^{*}$ and $G P I^{*}$ genotypes were analysed separately. All data were analysed with the General Linear Model (GLM) procedures incorporated in the SAS statistical package, and when significant differences among treatments were detected, multiple comparisons were made. As the number of data varied among treatments, we applied the LS-means method (SAS Institute 1998) for the multiple comparisons. Results from the same ANOVAs were added to complement explanations of significant phenotypegenotype interactions. For example, when Site $\times$ Genotype interactions were significant, barnacle sizes from each site (pooling each genotype data from 1 locus) were also compared.

ANCOVA performed using the GLM procedure of SAS was used to test differences in fecundity at different scales (micro-habitat, sites and regions) and their association with genotypes. Due to incomplete egg masses obtained from several samples, separate analyses for each cohort were performed with $\mathrm{n}=114$ samples for Cohort 2000 and $n=260$ for Cohort 2001 . Maximal barnacle length ( $\mathrm{mm}$ ) was used as a covariate of fecundity. In Cohort 2000, factors included in the analysis were Sites (Burnt Church and Cap Lumière), Microhabitat (HE, HS, LE, LS) and Genotype (3 for each gene). For Cohort 2001, factors were Region (north and south), Site nested within Region $(\mathrm{n}=4)$, Microhabitat $(\mathrm{n}=4)$ and Genotype $(\mathrm{n}=3)$.

\section{RESULTS}

\section{Barnacle growth and $G P I^{*}$ genotypes}

There was a significant association between variation in barnacle growth and GPI* genotypes for both cohorts. For Cohort 2000, the Date $\times$ Site $\times G P I^{*}$ genotype interaction was significant (Table 2), which was mainly due to 2 significant interactions showing that barnacles with a $G P I^{*} 286 / 286$ genotype were significantly larger than those with the GPI*100/100 genotype in Cap Lumière (southern region), both in October $(p=0.0158)$ and May $(p=0.0318)$ (Fig. 1a,b). For both comparisons, heterozygotes showed intermediate values between both homozygotes, but were not significantly different from either homozygote ( $p>0.05)$. Comparisons among sites (all individuals pooled for each site) also revealed that barnacle growth at Cap Lumière (southern region) was overall lower than that observed at Burnt Church (northern region) $(p<0.001$; Fig. 1c,d). Thus, genotype-growth association for GPI* 
Table 2. Semibalanus balanoides. Summary of factorial ANOVAs of size for Date, Microhabitat, Site and Region for both cohorts (2000 and 2001) and both Genotypes $\left(G P I^{*}\right.$ and $\left.M P I^{*}\right)$. Main effects and interactions not including genotype are not shown. Among the results not shown, the main factor Genotype was the only one that did not show significance ( $p>0.05)$. Micro: microhabitat; Geno: genotype. ${ }^{*} \mathrm{p}<0.05$

\begin{tabular}{|c|c|c|c|c|c|c|c|c|}
\hline \multirow{2}{*}{ Source of variation } & \multicolumn{4}{|c|}{$G P I^{*}$} & \multicolumn{4}{|c|}{$M P I^{*}$} \\
\hline & df & MS & $F$ & $\mathrm{p}$ & df & MS & $F$ & $\mathrm{p}$ \\
\hline \multicolumn{9}{|l|}{ Cohort 2000} \\
\hline Date $\times$ Site $\times$ Micro & 4 & 0.1477 & 17.65 & $<0.0001^{*}$ & 4 & 0.1222 & 14.51 & $<0.0001^{*}$ \\
\hline Date $\times$ Geno & 8 & 0.0123 & 1.47 & 0.1642 & 8 & 0.0069 & 0.82 & 0.5853 \\
\hline Site $\times$ Geno & 2 & 0.0144 & 1.72 & 0.1788 & 2 & 0.0133 & 1.58 & 0.2064 \\
\hline Date $\times$ Site $\times$ Geno & 8 & 0.0192 & 2.30 & $0.0188^{*}$ & 8 & 0.0084 & 1.00 & 0.4329 \\
\hline Micro $\times$ Geno & 6 & 0.0066 & 0.78 & 0.5827 & 6 & 0.0014 & 0.17 & 0.9845 \\
\hline Date $\times$ Micro $\times$ Geno & 24 & 0.0850 & 1.02 & 0.4348 & 24 & 0.0059 & 0.70 & 0.8548 \\
\hline Site $\times$ Micro $\times$ Geno & 2 & 0.0091 & 1.09 & 0.3353 & 2 & 0.0078 & 0.93 & 0.3961 \\
\hline Date $\times$ Site $\times$ Micro $\times$ Geno & 8 & 0.0129 & 1.55 & 0.1475 & 8 & 0.0138 & 1.63 & 0.1104 \\
\hline Error & 2045 & 0.0084 & & & 2007 & 0.0084 & & \\
\hline Corrected total & 2133 & & & & 2096 & & & \\
\hline \multicolumn{9}{|l|}{ Cohort 2001} \\
\hline Date $\times$ Site $($ Region $) \times$ Micro & 10 & 0.1303 & 14.20 & $<0.0001^{*}$ & 10 & 0.1527 & 16.91 & $<0.0001^{*}$ \\
\hline Date $\times$ Geno & 8 & 0.0056 & 0.61 & 0.7743 & 8 & 0.0064 & 0.71 & 0.6815 \\
\hline Region $\times$ Geno & 2 & 0.0051 & 0.55 & 0.5754 & 2 & 0.0230 & 2.55 & 0.0783 \\
\hline Date $\times$ Region $\times$ Geno & 8 & 0.0148 & 1.61 & 0.1152 & 8 & 0.0092 & 1.02 & 0.4154 \\
\hline Site $($ Region $) \times$ Geno & 4 & 0.0125 & 1.36 & 0.2455 & 4 & 0.0061 & 0.67 & 0.6108 \\
\hline Date $\times$ Site $($ Region $) \times$ Geno & 16 & 0.0082 & 0.90 & 0.5731 & 16 & 0.0095 & 1.05 & 0.3953 \\
\hline Micro $\times$ Geno & 6 & 0.0071 & 0.77 & 0.5927 & 6 & 0.0242 & 2.68 & $0.0133^{*}$ \\
\hline Date $\times$ Micro $\times$ Geno & 22 & 0.0109 & 1.19 & 0.2469 & 22 & 0.0140 & 1.55 & $0.0495^{*}$ \\
\hline Region $\times$ Micro $\times$ Geno & 6 & 0.0093 & 1.02 & 0.4118 & 6 & 0.0160 & 1.78 & 0.0997 \\
\hline Date $\times$ Region $\times$ Micro $\times$ Geno & 16 & 0.0155 & 1.69 & $0.0407^{*}$ & 16 & 0.0069 & 0.77 & 0.7229 \\
\hline Site $($ region $) \times$ Micro $\times$ Geno & 8 & 0.0087 & 0.95 & 0.4730 & 8 & 0.0163 & 1.81 & 0.0710 \\
\hline Date $\times$ Site $($ Region $) \times$ Micro $\times$ Geno & 20 & 0.0164 & 1.78 & $0.0170^{*}$ & 20 & 0.0121 & 1.34 & 0.1432 \\
\hline Error & 4896 & 0.0092 & & & 4863 & 0.0090 & & \\
\hline Corrected total & 5072 & & & & 5039 & & & \\
\hline
\end{tabular}

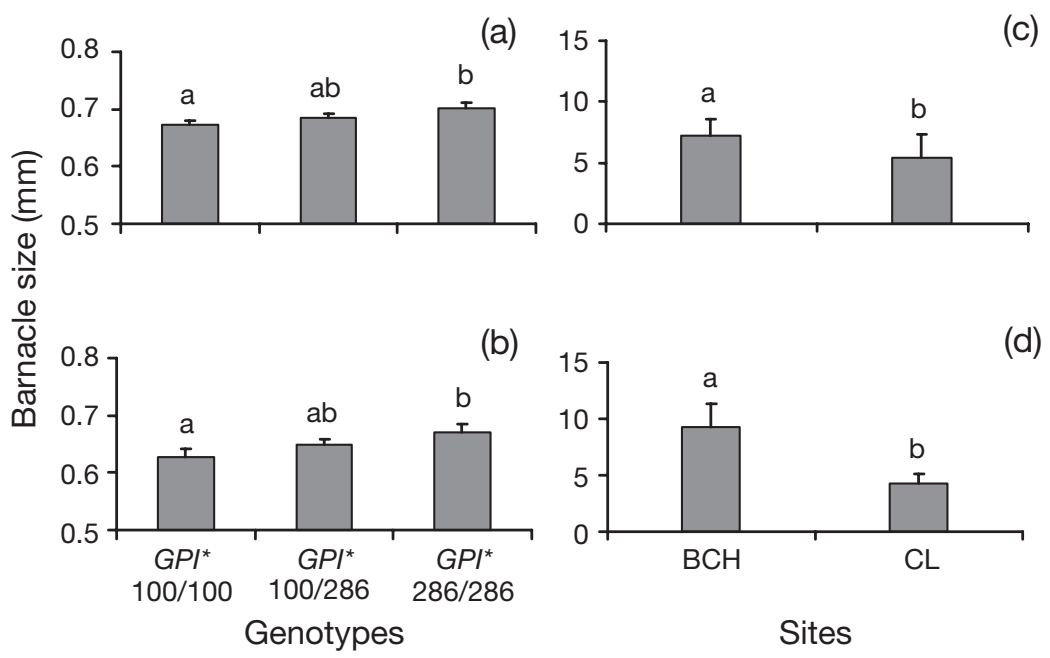

Fig. 1. Semibalanus balanoides. Barnacle size (log length) determined by LSmean analysis. (a-c) Relationships between barnacle size and $G P I^{*}$ genotype in Cohort 2000 for sites that contributed to the significant Date $\times$ Site $\times G P I^{*}$ genotype interaction. (a,b) Cap Lumière in (a) October, (b) May. (c,d) Mean barnacle size at different sites (all samples pooled) for Cohort 2000 in (c) October, (d) May. BCH: Burnt Church; CL: Cap Lumière. Bars sharing the same letter are not significantly different $(p>0.05)$. Error bars are $+\mathrm{SE}$ (c) was mainly observed in the southern region, where growth was most constrained.

For Cohort 2001, we observed a significant interaction for Date $\times$ Site (nested with region) $\times$ Microhabitat $\times$ GPI* genotype (Table 2), which was due to 4 significant differences in growth associated with $G P I^{*}$ genotypes, all observed in the southern region. As for Cohort 2000, individuals with the $G P I^{*} 286 / 286$ genotype were larger than those with the GPI*100/100 genotype (Fig. 2a-d; p < 0.05); heterozygotes $\left(G P I^{*} 100 / 286\right)$ were intermediate in all cases, but were not significantly different from homozygotes ( $p>0.05)$, except for the microhabitat HE on June 1 ( $\mathrm{p}=$ 0.0210) (Fig. 2a). As was also the case for Cohort 2000, comparisons among sites (all individuals pooled for each site) revealed that the genotype-growth 


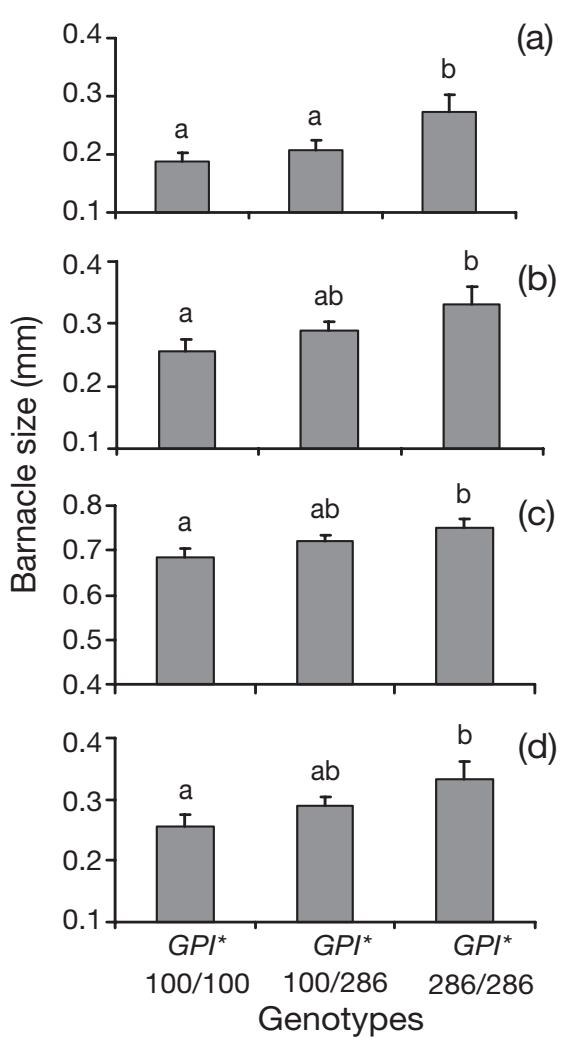

Fig. 2. Semibalanus balanoides. Barnacle size (log length) determined by LSmean analysis. (a-d) Relationships between barnacle size and $G P I^{*}$ genotype in Cohort 2001 for microhabitats that contributed to the significant Date $\times$ Site $(\mathrm{Re}-$ gion) $\times$ Microhabitat $\times G P I^{*}$ genotype interaction. (a) High exposed (HE) microhabitat (June 1) at Pointe Sapin. (b) Low sheltered (LS) microhabitat (June 2) at Pointe Sapin. (c) Low exposed (LE) microhabitat (August) at Cap Lumière. (d) High sheltered (HS) microhabitat (August) at Pointe Sapin. (e-h) Mean barnacle size at different microhabitats (pooled samples from the different sites) for Cohort 2001: (e) HE microhabitat on June 1; (f) LS on June 2; (g) LE on August; (h) HS on August. LG: Le Goulet; SH: Shippagan; PS: Pointe Sapin; CL: Cap Lumière. Bars sharing the same letter are not significantly different $(p>0.05)$. Error bars are $+\mathrm{SE}$

association for GPI* was mainly observed at sites and times where growth was most constrained (Fig. 2e-h; $\mathrm{p}<0.05)$.

\section{Barnacle growth and $M P I^{*}$ genotypes}

For Cohort 2000, no significant individual or interaction effects on barnacle growth associated with the $M P I^{*}$ genotypes were observed. However, for Cohort 2001, the analysis revealed a significant growth-MPI* genotype association as seen by the Date $\times$ Microhabitat $\times$ $M P I^{*}$ genotypes interaction (Table 2). For 3 out of 4 comparisons $M P I^{*} 100 / 100$ homozygotes exhibited higher growth than $M P I^{*} 85 / 85$ homozygotes. These significant interactions were observed in the LS microhabitat on June $1(p=0.0112)$, the LE microhabitat on June $2(p=$ 0.0066) and HS in August ( $p=0.0376$ ) (Fig. 3a,b,d). How- (e) ever, the LS microhabitat on June 2 showed an opposite pattern, where individuals with the $M P I^{*} 85 / 85$ genotype were significantly larger in size than individuals with the $M P I^{*} 100 / 100$ genotype $(p=$ 0.0062) (Fig. 3c). Heterozygotes did not show any clear tendency since intermediate growth was observed only in LE on June 2 (Fig. 3b, $\mathrm{p}=0.1534$ for $M P I^{*} 85 / 85$ and $\mathrm{p}=0.0668$ for $\left.M P I^{*} 100 / 100\right)$.

Comparisons among sites (pooled data) showed no clear pattern of association with the significant genotype-growth relationships (Fig. 3e-g); that is, there was no tendency for the genotypegrowth association at sites where growth was differentially constrained. Overall then, a weaker pattern of association between genotype and growth emerged from the analysis of $M P I^{*}$ in comparison to $G P I^{*}$.

\section{Fecundity}

The Size covariant revealed that barnacle size correlated positively with barnacle fecundity ( $p<0.0001$; Table 3 ). In contrast to what was observed for growth, no significant associations between genotypes and fecundity were observed for the 2 cohorts (2000 and 2001) and loci $\left(G P I^{*}\right.$ and $\left.M P I^{*}\right)$. Significant differences were only associated with site (Table 3). In Cohort 2000, barnacles from Burnt Church (northern region) contained more larvae (nauplii I) per individual than those from Cap Lumière (southern region) (mean $635.0 \pm 656.3$ and $114 \pm 336.0$ larvae ind. ${ }^{-1}$, respectively; $\mathrm{p}=0.0015)$. In Cohort 2001, barnacles from Le Goulet (northern region) exhibited higher fecundity than those from all other sites (mean: $1138.5 \pm 679.7$ larvae ind. ${ }^{-1}$; Shippagan, $p=0.0071$, Cap Lumière, $p=$ 0.0114 and Pointe Sapin, $\mathrm{p}<0.0001$ ). In the same analysis, individuals from Shippagan (northern region) and Cap Lumière (southern region) showed similar fecundity $\left(1044.7 \pm 716.6\right.$ and $767.8 \pm 623.9$ larvae ind.$^{-1}$; respectively, $\mathrm{p}=0.6486$ ) with those from Pointe Sapin (southern region) exhibiting lower fecundity than those from other sites $\left(287.2 \pm 679.7\right.$ larvae ind.$^{-1} ; \mathrm{p}<0.0001$ at Shippagan and Cap Lumière). Overall, for both cohorts, barnacles from the southern region tended to exhibit low fecundity compared to those from the northern region. However, fecundity was not associated with $M P I^{*}$ or $G P I^{*}$ genotypes. 

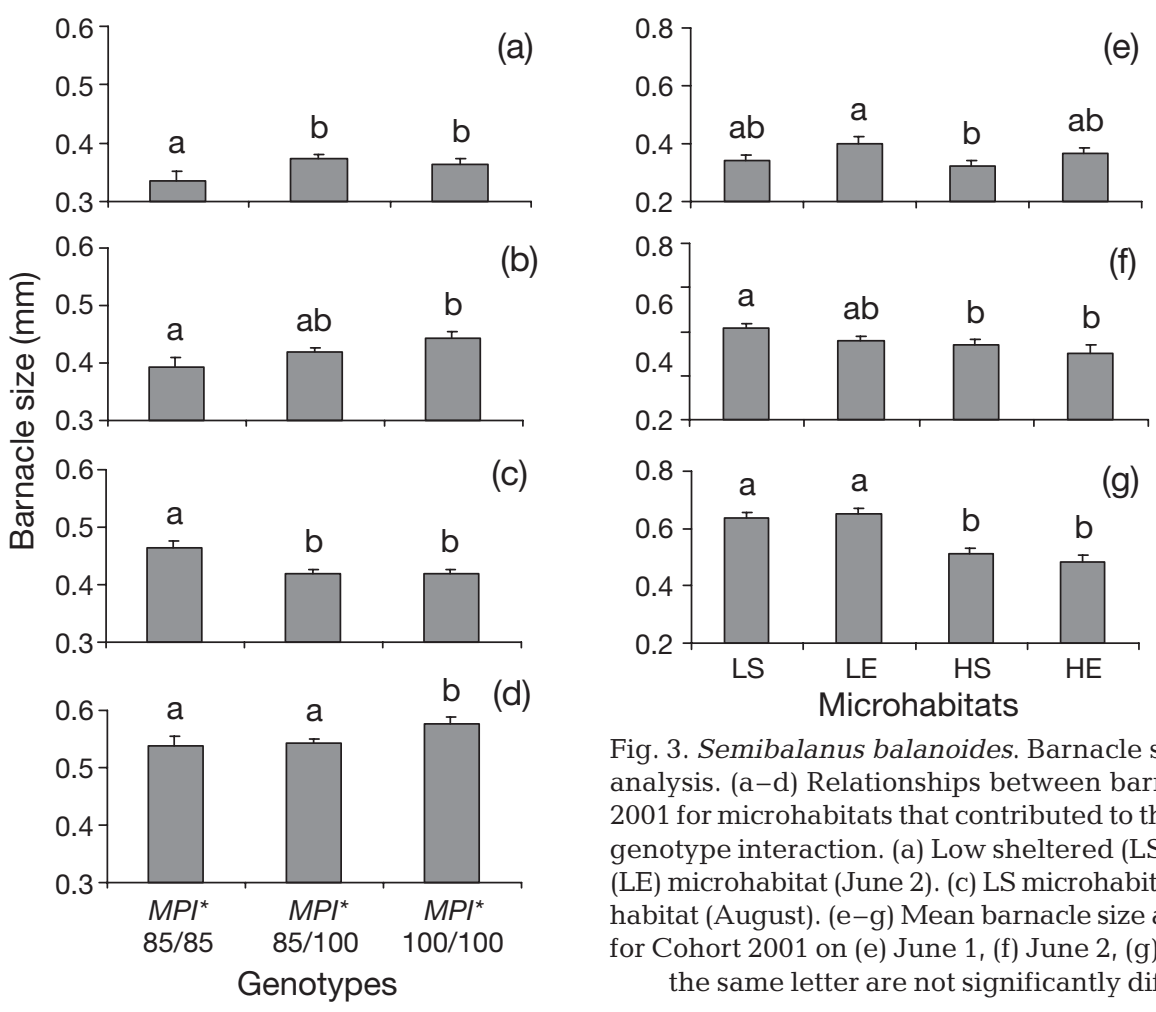

Fig. 3. Semibalanus balanoides. Barnacle size (log length) determined by LS-mean analysis. (a-d) Relationships between barnacle size and $M P I^{*}$ genotype in Cohort 2001 for microhabitats that contributed to the significant Date $\times$ Microhabitat $\times M P I^{*}$ genotype interaction. (a) Low sheltered (LS) microhabitat (June 1). (b) Low exposed (LE) microhabitat (June 2). (c) LS microhabitat (June 2). (d) High sheltered (HS) microhabitat (August). (e-g) Mean barnacle size at different microhabitats (all sites pooled) for Cohort 2001 on (e) June 1, (f) June 2, (g) August. HE: high exposed. Bars sharing the same letter are not significantly different $(p>0.05)$. Error bars are $+\mathrm{SE}$

Table 3. Semibalanus balanoides. Summary of ANCOVA analysis for fecundity variation at different scales (Microhabitat, Site and Region) and Genotypes (GPI* and $\left.M P I^{*}\right)$ for both cohorts (2000 and 2001). Barnacle Size (mm) was used as a covariant. Micro: microhabitat; Geno: genotype. ${ }^{*} \mathrm{p}<0.05$

\begin{tabular}{|c|c|c|c|c|c|c|c|c|}
\hline \multirow[t]{2}{*}{ Source of variation } & \multicolumn{4}{|c|}{$G P I^{*}$} & \multicolumn{4}{|c|}{$M P I^{*}$} \\
\hline & $\mathrm{df}$ & MS & $F$ & $\mathrm{p}$ & df & MS & $F$ & $\mathrm{p}$ \\
\hline \multicolumn{9}{|l|}{ Cohort 2000} \\
\hline Size & 1 & 46.7270 & 86.14 & $<0.0001^{*}$ & 1 & 50.0680 & 95.36 & $<0.0001^{*}$ \\
\hline Site & 1 & 3.0821 & 5.68 & $0.0191^{*}$ & 1 & 5.5852 & 10.64 & $0.0015^{*}$ \\
\hline Micro & 3 & 0.5948 & 1.10 & 0.3545 & 3 & 1.3152 & 2.50 & 0.0637 \\
\hline Geno & 2 & 0.0638 & 0.12 & 0.8891 & 2 & 0.6519 & 1.24 & 0.2935 \\
\hline Site $\times$ Micro & 1 & 1.5342 & 2.83 & 0.0959 & 1 & 1.0779 & 2.05 & 0.1552 \\
\hline Site $\times$ Geno & 2 & 0.4233 & 0.78 & 0.4612 & 2 & 0.9762 & 1.86 & 0.1514 \\
\hline Micro $\times$ Geno & 6 & 0.1778 & 0.33 & 0.9208 & 6 & 0.2221 & 0.42 & 0.8621 \\
\hline Site $\times$ Micro $\times$ Geno & 2 & 0.0396 & 0.07 & 0.9297 & 2 & 0.0208 & 0.04 & 0.9612 \\
\hline Error & 96 & 0.5425 & & & 96 & 0.5251 & & \\
\hline Corrected total & 114 & & & & 114 & & & \\
\hline \multicolumn{9}{|l|}{ Cohort 2001} \\
\hline Size & 1 & 87.1290 & 285.42 & $<0.0001^{*}$ & 1 & 86.7210 & 273.92 & $<0.0001^{*}$ \\
\hline Region & 1 & 6.8829 & 22.50 & $<0.0001^{*}$ & 1 & 3.9159 & 12.37 & $0.0005^{*}$ \\
\hline Site(Region) & 2 & 7.5694 & 24.80 & $<0.0001^{*}$ & 2 & 7.0611 & 22.30 & $<0.0001^{*}$ \\
\hline Micro & 2 & 0.2293 & 0.75 & 0.4730 & 2 & 0.0668 & 0.21 & 0.8100 \\
\hline Geno & 2 & 0.2556 & 0.84 & 0.4342 & 2 & 0.0172 & 0.05 & 0.9470 \\
\hline Region $\times$ Micro & 2 & 0.2649 & 0.87 & 0.4213 & 2 & 0.3294 & 1.04 & 0.3550 \\
\hline Site(Region) $\times$ Micro & 2 & 0.0228 & 0.07 & 0.9281 & 2 & 0.1243 & 0.39 & 0.6757 \\
\hline Region $\times$ Geno & 2 & 0.5803 & 1.90 & 0.1518 & 2 & 0.1762 & 0.56 & 0.5739 \\
\hline Site $($ Region $) \times$ Geno & 4 & 0.2326 & 0.76 & 0.5510 & 4 & 0.2174 & 0.69 & 0.6018 \\
\hline Micro $\times$ Geno & 4 & 0.1130 & 0.37 & 0.8299 & 4 & 0.1621 & 0.51 & 0.7270 \\
\hline Region $\times$ Micro $\times$ Geno & 4 & 0.3792 & 1.24 & 0.2938 & 4 & 0.3201 & 1.01 & 0.4024 \\
\hline Site $($ Region $) \times$ Micro $\times$ Geno & 4 & 0.5460 & 1.79 & 0.1319 & 4 & 0.2551 & 0.81 & 0.5227 \\
\hline Error & 230 & 0.3053 & & & 230 & 0.3166 & & \\
\hline Corrected total & 260 & & & & 260 & & & \\
\hline
\end{tabular}




\section{DISCUSSION}

The main goal of this study was to test the null hypothesis of no association between the variation in 2 fitness-related traits (growth and fecundity) and polymorphism for both the MPI* and $G P I^{*}$ genotypes. We then tested whether or not such an association, if present, was related to the genotype selection observed for both allozymes at our sampling locations. Our results rejected the null hypothesis for GPI*, which provided evidence that this enzyme may influence growth under natural conditions. However, this association was expressed only in specific environments where growth was apparently constrained relative to other habitats. In contrast, no clear pattern of an association between growth and genotype emerged for $M P I^{*}$, nor for a relationship between fecundity and genotypes for either locus.

\section{Growth-GPI* genotype association}

Several authors have previously suggested that specific $G P I^{*}$ genotypes have an adaptive nature (Watt et al. 1985, Hawkins et al. 1989, Patarnello \& Battaglia 1992), based on the metabolic role of the GPI enzyme. GPI occupies an important regulatory region between glycogen storage and glycolysis, and for some organisms minor differences in habitat are sufficient for the selection of specific alleles with different kinetic properties (Hawkins 1996). Our study provides several lines of evidence for the association between the intensity of genotype selection and growth-GPI* in the acorn barnacle. (1) Both the growth-genotype association and genotype selection apparently occur in the southern region only (Véliz et al. 2004, present study). Thus, when individuals with the $G P I^{*} 100 / 100$ genotype were smaller than individuals with the $G P I^{*} 100 / 286$ or $G P I^{*} 286 / 286$ genotype, this genotype also occurred less frequently in this region (see Véliz et al. 2004). This phenomenon was confirmed by data from 2 independent cohorts and occurred in the southern region only. (2) Both genotype selection and a growth-GPI* genotype association confirmed the same type of selection acting on genotypes characterized by additive effects. That is to say, heterozygote $G P I^{*} 100 / 286$ individuals showed intermediate growth, ranging between that of $G P I^{*} 100 / 100$ and $G P I^{*} 286 / 286$. Similarly, fitness estimates in terms of differential survival at time of settlement were significantly smaller for $G P I^{*} 100 / 100$ than for $G P I^{*} 286 / 286$, with heterozygotes having an intermediate value (Véliz et al. 2004, 2006). (3) When a growth-GPI* genotype association was detected, barnacles were generally smaller than barnacles from other sites at the same date, suggesting that selection is more intense when conditions for growth are more limiting.

In Semibalanus balanoides, selection of GPI* genotypes thus seems to act on 2 different levels in the southern region. (1) Selection reduces the number of individuals with the genotype, resulting in lower performance in a given habitat ('lethal phase'). Thus, within a few days after settlement in the southern region, the frequency of individuals with the $G P I^{*}$ 100/100 genotype decreased drastically from 0.53 to 0.34 (Cohort 2001) (Véliz et al. 2004). Evidence from $A D H^{*}$ in Drosophila (Freriksen et al. 1994) and LAP* in Mytilus edulis (Koehn et al. 1980) also corroborate the idea that lethal selection on genotypes acts early in the development of the organism. For example, $A D H^{*}$ alleles may be subject to selective and/or neutral processes of varying strengths during different fruit fly life stages, processes which have strong effects on the larval but not the adult stages (Heinstra et al. 1987, Freriksen et al. 1994). (2) Selection may further reduce the performance of a genotype which already has a low performance ('sublethal effect'). In the southern region and following reduction in the frequency of the GPI*100/100 genotype, individuals with this genotype were smaller than individuals with $G P I^{*} 100 / 286$ or $G P I^{*} 286 / 286$. Susceptibility to stress (e.g. desiccation) may decrease in adult organisms relative to younger life stages, because there is a decrease in the surface area to volume ratio (Foster 1971). Thus, it is plausible that selection changes from lethal to sub-lethal, because growing individuals show more resistance to stress than early juveniles.

This scenario assumes that the selective factors acting in the southern region persist throughout barnacle life, reducing genotype performance (e.g. growth) when lethal selection occurs a few days after settlement. As we recently proposed (Véliz et al. 2004), differences in the food concentration (microalgae) between the northern and southern region might cause differences in the nutritional condition of premetamorphic larvae due to different genotype performance. Thus, differences in the microalgae concentration could be manifested at all benthic stages, maintaining differences in individual growth due to different genotypes as low microalgae concentrations persist during summer in the southern region (Steven 1974). However, data on the microalgae concentration for the years 2000 and 2001, which would have allowed us to more firmly establish a direct effect of food concentration on genotype-phenotype association, were not available.

Because microalgae concentration displays intraand inter-annual variation in the Gulf of St. Lawrence 
(de Lafontaine et al. 1991), this variation could also explain differences in the growth-genotype associations observed between cohorts. Briefly, the associations observed in October and May at the site level in Cohort 2000 and between June and August at the microhabitat level in Cohort 2001 could be due to such intra- and inter-annual variation. Empirical evidence for temporal variation in selective regimes caused by temporal variation in environmental conditions has been documented in invertebrates (e.g. Borash et al. 1998, Mateus \& Sene 2003), fishes (e.g. Reimchen \& Nosil 2002, Aubin-Horth \& Dodson 2004) and plants (e.g. Weinig et al. 2003). For example, spatial and temporal variation (intra- and inter-annual) in directional selection was found for hatching date in both first- and late-clutch hatchlings in the lizard Uta stansburiana (Svensson \& Sinervo 2004).

\section{Growth-MPI* genotype association}

Evidence is accumulating for several marine invertebrates, including Semibalanus balanoides, that $M P I^{*}$ genotype frequency changes among habitats (Hedgecock 1986, McDonald 1990, Schmidt \& Rand 1999, Véliz et al. 2004, 2006), which suggests that an interaction with phenotypes is generally more prevalent than reported for $G P I^{*}$. Yet, this was not observed in our study. Whereas strong genotype selection was observed for both cohorts (Véliz et al. 2004) in the southern region of the Gulf of St. Lawrence, a growth$M P I^{*}$ genotype association was observed only for Cohort 2001 on the microhabitat scale with an inverse relationship in 1 case (LS microhabitat; June 1 vs. June 2, Fig. 3a,c). In contrast, a laboratory study conducted with barnacles from Maine (USA) showed a clear association between growth and MPI* genotypes (Schmidt 2001). Thus, in treatments under high stress conditions (high temperature and the presence of mannose), barnacles with the $M P I^{*} 100 / 100$ genotype grew faster than $M P I^{*} 85 / 85$ homozygotes. However, it has also been reported that this pattern was reversed in more southern populations (Rhode Island, USA), resulting in changes in genotype frequencies due to selection similar to what we observed in the Gulf of St. Lawrence but on a larger geographic scale (Rand et al. 2002). Thus, all evidence (Maine, Rhode Island and Gulf of St. Lawrence) suggests that $M P I^{*}$ genotype selection and its association with growth may be more difficult to disentangle than $G P I^{*}$ genotype selection or that it is possibly less associated with the growth of individuals. Clearly, further analyses will be necessary to elucidate the real pattern of selection acting on $M P I^{*}$ in barnacles and its possible association with variations in fitness-related traits.

\section{Fecundity}

Association between fecundity and genotype was expected to be high, since fecundity is associated with the heterozygosity of allozymes in several organisms, including Mytilus (Rodhouse et al. 1986), Drosophila (Serradilla \& Ayala 1983) and Pinus 'ponderosa pine' (Linhart \& Mitton 1985). Moreover, the correlation between size and fecundity in barnacles and the association between growth and GPI* genotype association in the present study further reinforced this expectation. Whereas no phenotypegenotype association was detected for fecundity, we cannot rule out the possibility that our study lacked the statistical power to produce evidence for such an association. Thus, while our analysis confirms an association between fecundity and size, the difficulty of obtaining a complete larvae mass from many individuals sampled directly from the intertidal may have limited our ability to detect a fecundity-genotype association.

\section{CONCLUSIONS}

This study provided evidence that genotypic variation in enzymatic loci may influence the growth of barnacles under natural conditions. Since mortality rates generally decrease with increasing body size (Peterson \& Wroblewski 1984, Sogard 1997, Schmidt 2001), individuals that grow more rapidly should spend less time in the more vulnerable size classes. Larger individuals should produce more progeny, making a more important genetic contribution (in terms of genotype frequency) to the next generation compared to smaller individuals. Our study has also demonstrated the importance of temporal and spatial sampling to determine the scale at which natural selection acts. It shows that selection may be a dynamic process that works in different ways, first by affecting genotype frequencies and later by changing fitness, at least in barnacle growth. Overall, this study exemplifies the usefulness of testing for associations between genotypic variation and fitness-related traits in order to elucidate the importance of balanced polymorphism for the persistence of species striving to exist in heterogeneous environments.

Acknowledgements. We thank L. Lapointe, G. Daigle, L. M. Pardo and M. Cusson for statistical assistance. We are grateful to D. J. Fraser and S. M. Rogers for comments and corrections of the manuscript. This work was supported by the Fonds FCAR (Québec) and NSERC (Canada) grants to E.B. and L.B. This study is a contribution to the research programme of Québec-Océan. 


\section{LITERATURE CITED}

Aubin-Horth N, Dodson JJ (2004) Influence of individual body size and variable thresholds on the incidence of a sneaker male reproductive tactic in Atlantic salmon. Evolution 58:136-144

Barnes H (1959) Temperature and the life cycle of Balanus balanoides (L.). In: Ray DL (ed) Marine boring and fouling organisms. University of Washington Press, Seattle, WA, p 234-245

Barnes H, Barnes M (1965) Egg size, nauplius size, and their variation with local, geographical, and specific factors in some common cirripedes. J Anim Ecol 34:391-402

Barnes H, Barnes M (1976) The rate of development of the embryos of Balanus balanoides (L.) from a number of European and American populations and the designation of local races. J Exp Mar Biol Ecol 24:251-269

Barnes H, Crisp DJ (1956) Evidence of self-sertilization in certain species of barnacles. J Mar Biol Assoc UK 35:631-639

Bassindale R (1936) The developmental stages of three English barnacles: Balanus balanoides (Linn.), Chtamalus stellatus (Poli) and Verruca stroemia (O.F. Müller). Proc Zool Soc Lond 106:57-74

Bergeron P, Bourget E (1984) Effet du froid et des glaces sur les peuplements intertidaux des régions nordiques, particulièrement dans l'estuaire du Saint-Laurent. Oceanis 10:279-304

Bergeron P, Bourget E (1986) Shore topography and spatial partitioning of crevice refuges by sessile epibenthos in an ice disturbed environment. Mar Ecol Prog Ser 28:129-145

Bertness MD, Gaines SD (1993) Larval dispersal and local adaptation in the acorn barnacle. Evolution 47:316-320

Borash DJ, Gibbs AG, Joshi A, Mueller LD (1998) A genetic polymorphism maintained by natural selection in a temporally varying environment. Am Nat 151:148-156

Bousfield EL (1953) The distribution and spawning seasons of barnacles on the Atlantic coast of Canada. Bull Natl Mus Can 132:112-154

Bousfield EL (1955) Ecological control of the occurrence of barnacles in the Miramichi Estuary. Bull Natl Mus Can 137:1-69

Brind'Amour A, Bourget E, Tremblay R (2002) Fecundity, growth rate and survivorship at the interface between two contiguous genetically distinct groups of Semibalanus balanoides. Mar Ecol Prog Ser 229:173-184

de Lafontaine Y, Demers S, Runge J (1991) Pelagic food web interaction and productivity in the Gulf of St. Lawrence: a perspective. In: Terriault JC (ed) The Gulf of St. Lawrence: small ocean or big estuary? Can Spec Publ Fish Aquat Sci 113:99-123

Diehl WJ, Koehn RK (1985) Multiple-locus heterozygosity, mortality, and growth in a cohort of Mytilus edulis. Mar Biol 88:265-271

Dimichele L, Powers DA (1991) Allozyme variation, developmental rate, and differential mortality in the teleost Fundulus heteroclitus. Physiol Zool 64:1426-1443

Dufresne F, Bourget E, Bernatchez L (2002) Differential patterns of spatial divergence in microsatellite and allozyme alleles: further evidence for locus-specific selection in the acorn barnacle, Semibalanus balanoides? Mol Ecol 11: 113-123

Feder ME, Watt WB (1992) Functional biology of adaptation. In: Berry RJ, Crawford TJ, Hewitt GM (eds) Genes in ecology. Blackwell Scientific Publications, London, p 365-392

Foster BA (1971) Desiccation as a factor in the intertidal zonation of barnacles. Mar Biol 8:12-29

Freriksen A, Seykens D, Heinstra PWH (1994) Differences between larval and adult Drosophila in metabolic degradation of ethanol. Evolution 48:504-508

Gillespie JH, Kojima K (1968) The degree of polymorphism in enzymes involved in energy production compared to that in nonspecific enzymes in two Drosophila ananassae populations. Proc Natl Acad Sci USA 61:582-585

Hansson B, Westerberg L (2002) On the correlation between heterozygosity and fitness in natural populations. Mol Ecol 11:2467-2474

Hawkins AJS (1996) Temperature adaptation and genetic polymorphism in aquatic animals. In: Johnston IA, Bennett AF (eds) Animals and temperature: phenotypic and evolutionary adaptation. Cambridge University Press, Cambridge, p 103-125

Hawkins AJS, Bayne BL, Day AJ, Rusin J, Worrall CM (1989) Genotype-dependent interrelations between energy metabolism, protein metabolism and fitness. In: Ryland JS, Tyler PA (eds) Reproduction, genetics and distributions of marine organisms. Olsen \& Olsen, Fredensborg, p 283-292

Hebert PDN, Beaton MJ (1989) Methodologies for allozyme analysis using cellulose acetate electrophoresis: a practical handbook. Helena Laboratoires, Beaumont, TX

Hedgecock D (1986) Is gene flow from pelagic larval dispersal important in the adaptation and evolution of marine invertebrates? Bull Mar Sci 39:550-564

Heinrich B (1977) Why have some animals evolved to regulate a high body temperature? Am Nat 111:623-640

Heinstra PWH, Scharloo W, Thorig GEW (1987) Physiological significance of the alcohol dehydrogenase polymorphism in larvae of Drosophila. Genetics 117:75-84

Holm ER, Bourget E (1994) Selection and population genetic structure of the barnacle Semibalanus balanoides in the northwest Atlantic and Gulf of St. Lawrence. Mar Ecol Prog Ser 113:247-256

Koehn RK, Newell RIE, Immermann F (1980) Maintenance of an aminopeptidase allele frequency cline by natural selection. Proc Natl Acad Sci USA 77:5385-5389

Koehn RK, Zera AJ, Hall JC (1983) Enzyme polymorphism and natural selection. In: Nei $M$, Koehn RK (eds) Genes and proteins. Sinauer Associates, Sunderland, MA, p 115-136

Kojima KJ, Gillespie YN, Tobari YN (1970) A profile of Drosophila species' enzymes assayed by electrophoresis. I. Number of alleles, heterozygosities, and linkage disequilibrium in glucose-metabolizing systems and some other enzymes. Biochem Genet 4:627-637

Linhart YB, Mitton JF (1985) Relationship among reproduction, growth rates, and protein heterozygosity in ponderosa pine. Am J Bot 72:181-184

Mateus RP, Sene FM (2003) Temporal and spatial allozyme variation in the south American cactophilic Drosophila antonietae (Diptera; Drosophilidae). Biochem Genet 41: 219-233

McDonald JH (1990) Contrasting amounts of geographical variation as evidence for direct selection: MPI and PGM loci in eight crustacean species. Heredity 67:215-219

Mitton JB (1997) Selection in natural populations. Oxford University Press, New York

Montgomery DC (2001) Design and analysis of experiments, 5th edn. John Wiley \& Sons, New York

Patarnello T, Battaglia B (1992) Glucose phospate isomerase and fitness: effects of temperature on genotype dependent mortality and enzyme activity in two species of the genus Gammarus (Crustacea: Amphipoda). Evolution 46: 1568-1571

Peterson I, Wroblewski JS (1984) Mortality rate of fishes in the pelagic ecosystem. Can J Fish Aquat Sci 41:1117-1120 
Planes S, Romans P (2004) Evidence of genetic selection for growth in new recruits of a marine fish. Mol Ecol 13: 2049-2060

Powers DA, Laverman T, Crawford D, Dimichele L (1991) Genetic mechanisms for adapting to a changing environment. Annu Rev Genet 25:629-659

Raffaelli D, Hawkins S (1996) Intertidal ecology. Chapman \& Hall, New York

Ramirez E (2002) Fecundity and life-history strategies in marine invertebrates. Adv Mar Biol 43:87-170

Rand DM, Spaeth PS, Sackton TB, Schmidt PS (2002) Ecological genetics of MPI and GPI polymorphisms in the acorn barnacle and the spatial scale of neutral and non-neutral variation. Integr Comp Biol 42:825-836

Reimchen TE, Nosil P (2002) Temporal variation in divergent selection on spine number in threespine stickleback. Evolution 56:2472-2483

Rodhouse PG, McDonald JH, Newell RIE, Koehn RK (1986) Gamete production, somatic growth and multiple locus heterozygosity in Mytilus edulis L. Mar Biol 90:209-214

SAS Institute (1998) SAS/STAT user's guide, version 8. SAS Institute, Cary, NC

Schmidt PS (2001) The effects of diet and physiological stress on the evolutionary dynamics of an enzyme polymorphism. Proc R Soc Lond Ser B 268:9-14

Schmidt PS, Rand DM (1999) Intertidal microhabitat and selection at $\mathrm{MPI}^{*}$ : interlocus contrasts in the northern acorn barnacle, Semibalanus balanoides. Evolution 53: 135-146

Serradilla JM, Ayala JF (1983) Effects of allozyme variation on fitness components in Drosophila melanogaster. Genetica 62:139-146

Sogard SM (1997) Size-selective mortality in the juvenile stage of teleost fishes: a review. Bull Mar Sci 60:1129-1157

Southward AJ (1958) Note on the temperature tolerances of some intertidal animals in relation to environmental tem-

Editorial responsibility: Otto Kinne (Editor-in-Chief), Oldendorf/Luhe, Germany peratures and geographical distribution. J Mar Biol Assoc UK 37:49-66

Steven PM (1974) Primary and secondary production in the Gulf of St Lawrence. Marine Sciences Center, McGill University, Montreal

Svensson EI, Sinervo B (2004) Spatial scale and temporal component of selection in side-blotched lizards. Am Nat 163:726-734

Tremblay R, Myrand B, Sevigny JM, Blier P, Guderley H (1998) Bioenergetic and genetic parameters in relation to susceptibility of blue mussels, Mytilus edulis (L.) to summer mortality. J Exp Mar Biol Ecol 221:27-58

Véliz D, Bourget E, Bernatchez L (2004) Regional variation in the spatial scale of selection at $M P I^{*}$ and $G P I^{*}$ in the acorn barnacle Semibalanus balanoides (Crustacea). J Evol Biol 17:953-966

Véliz D, Duchesne P, Bourget E, Bernatchez L (2006) Stable genetic polymorphism in heterogeneous environments: balance between asymmetrical dispersal and selection in the acorn barnacle. J Evol Biol (in press)

Watt WB (1992) Eggs, enzymes, and evolution - natural variants change insect fecundity. Proc Nat Acad Sci USA 89: 10608-10612

Watt WB (1994) Allozymes in evolutionary genetics: selfimposed burden or extraordinary tool? Genetics 136: $11-16$

Watt WB, Cassin RC, Swan MS (1983) Adaptation at specific loci. III. Field behavior and survivorship differences among Colias PGI genotypes are predictable from in vitro biochemistry. Genetics 103:725-739

Watt WB, Carter PA, Blower SM (1985) Adaptation at specific loci. IV. Differential mating success among glycolytic allozyme genotypes of Colias butterflies. Genetics 109:157-175

Weinig C, Dorn LA, Kane NC, German ZM and 6 others (2003) Heterogeneous selection at specific loci in natural environments in Arabidopsis thaliana. Genetics 165:321-329

Submitted: February 9, 2005; Accepted: September 1, 2005 Proofs received from author(s): January 11, 2006 